\title{
Perception, knowledge and
} freedom in the age of extremes: on the historical epistemology of Ludwik Fleck and Michael Polanyi

\section{Journal Article}

Author(s):

Hagner, Michael

Publication date:

2012-05

Permanent link:

https://doi.org/10.3929/ethz-b-000048518

Rights / license:

In Copyright - Non-Commercial Use Permitted

Originally published in:

Studies in East European Thought 64(1-2), https://doi.org/10.1007/s11212-012-9162-6 


\title{
Perception, knowledge and freedom in the age of extremes: on the historical epistemology of Ludwik Fleck and Michael Polanyi
}

\author{
Michael Hagner
}

Published online: 21 March 2012

(C) Springer Science+Business Media B.V. 2012

\begin{abstract}
This paper deals with Ludwik Fleck's theory of thought styles and Michael Polanyi's theory of tacit knowledge. Though both concepts have been very influential for science studies in general, and both have been subject to numerous interpretations, their accounts have, somewhat surprisingly, hardly been comparatively analyzed. Both Fleck and Polanyi relied on the physiology and psychology of the senses in order to show that scientific knowledge follows less the path of logical principles than the path of accepting or rejecting specific conventions, where these may be psychologically or sociologically grounded. It is my aim to show that similarities and differences between Fleck and Polanyi are to be seen in the specific historical and political context in which they worked. Both authors, I shall argue, emphasized the relevance of perception in close connection to their respective understanding of science, freedom, and democracy.
\end{abstract}

Keywords Ludwik Fleck · Michael Polanyi · Perception - Gestalt psychology · Democracy

\section{Introduction: perception and scientific knowledge}

Reflection about scientific knowledge cannot ignore perception. One can either be of the opinion that the senses are the golden path to knowledge; in the philosophical

An earlier version of this article was first published in German under the title „Sehen, Gestalt und Erkenntnis im Zeitalter der Extreme. Zur historischen Epistemologie von Ludwik Fleck und Michael Polanyi”. In: L. Bader, M. Gaier \& F. Wolf (Eds.), Vergleichendes Sehen (pp. 575-595). Paderborn: Fink 2010. For the present version, the paper was revised and extended. I am grateful to an anonymous referee for critical comments and to Carrie Assman for her translation of this text.

M. Hagner $(\bowtie)$

ETH Zürich, Zürich, Switzerland

e-mail: mhagner@ethz.ch 
tradition, this is the position of sensationalism and phenomenology. Or one can argue conversely that the senses impede our progress toward knowledge and are irrelevant at the least; this position has been held by various forms of rationalism. In this paper, I am interested less in this philosophical debate, which has been magisterially analyzed by Martin Jay (1994) with respect to French rationalism in the twentieth century, than in the relevance of perception for theories of scientific knowledge. More specifically, I am concerned with Ludwik Fleck's theory of thought styles and Michael Polanyi's theory of tacit knowledge. Both concepts have been very influential for science studies in general, and both have been subject to numerous interpretations. It has also been pointed out by several commentators that sensory perception and theories of perception have been quite important for Fleck and Polanyi in the way that sensory perception represents an indispensable basis for knowledge (Smith 1988; Jha 2002; Zittel 2012). More precisely-scientific knowledge does not essentially differ in its process from perception and must thus be seen as a genuinely human activity. Fleck and Polanyi relied on the physiology and psychology of the senses in order to show that scientific knowledge follows less along the path of logical principles than along the path of accepting or rejecting specific conventions. Categories that have since become canonical such as thought style, thought collective (Denkstil, Denkkollektiv) or tacit knowledge cannot be understood in their theoretical origin without reference to the psycho-physiology of the senses. Although Fleck's and Polanyi's orientation toward perception is well known, their accounts have, somewhat surprisingly, hardly been comparatively analyzed. In the following, I want to show that similarities and differences between Fleck and Polanyi are to be seen in the specific historical and political context in which they worked. Both authors, I shall argue, emphasized the relevance of perception in close connection to their respective understanding of science, freedom, and democracy.

Before examining this-let's say-scopic epistemology more closely in the following, I would like to begin by roughly sketching the alternative theory, according to which the senses are more or less excluded from knowledge generation. As far as I can see, there have been two major strategies to denigrate perception. The first one is based on the idea that media, instruments, and apparatuses represent a fundamental intervention in the process of perception. What we perceive is an effect of material construction and a function of these instruments. Accordingly, there is a medial a priori of perception and thus also of knowledge. We are no longer masters of our view of the world which we have delegated to instruments. Instruments have replaced the eye, or to put it differently-they are the true eye of the scientist, who no longer needs to rely on deceptive, unreliable senses. This position was maintained by the nineteenth-century astronomer Jules Janssen when he writes, the camera is "the true retina of the scientist" (Janssen 1888). Photography may accomplish what the eye cannot, namely produce the reliable image that can be stored and reproduced. Janssen eliminated the eye of the observer but not the scopic principle. Knowledge remained to be understood in terms of perception, even if perception was regarded as a trait of the instrument. 
In French epistemology of the twentieth century, however, the scopic principle was abandoned in general. ${ }^{1}$ It was Gaston Bachelard, who placed the progress of scientific knowledge in radical contrast to sensory perception. For Bachelard, knowledge proceeds against sight, against the continuous, the obvious, all that is close at hand; it is the result of the "rupture epistemologique," thus representing a break with ruling convention. Contemporary science-Bachelard is referring above all to physics - is distinguished by the fact that it has broken with the pre-history of sensory evidence. According to him, science thinks through the apparatus, not through sense organs (Bachelard 1951, 84). The radicality of this position consists in the fact that the point is no longer to characterize the sense organs as derivatives, nor to assume the converse, namely that instruments are simply the better sense organs (Kittler 1999, 22-32). This position holds rather that the senses should be excluded from the epistemic process altogether.

The second strategy to abandon perception has been to develop a logic of scientific knowledge production. Thomas Kuhn's famous article about the Logic of Discovery or Psychology of Research alludes to this point. On the one hand, psychology assumes that the sources of knowledge lie in the researcher, while on the other hand the logic of discovery contends that intersubjectively linkable structures - such as objectivity, proof, rationality, or even logic are the primary determinants of the fundamentals of epistemology (Kuhn 1970, 22). With this differentiation Kuhn referred implicitly to the famous distinction between the "context of discovery" and the "context of justification," which was drawn in the programmatic statement of the Vienna Circle and fully developed by Hans Reichenbach (Carnap et al. 1981, 307; Reichenbach 1962, 231). Reichenbach and his colleagues in Vienna aimed at separating the contingencies of personality, passion, intuition, and local environment characteristic of the context of discovery of scientific knowledge from the logical, objective, rational context of justification. The first, with all of its subjective components, including sensory perception, has, according to Reichenbach, no place in a theory of science, because subjective factors will not yield general statements.

Reichenbach and other logical empiricists believed models for such generalizations are to be found in physical propositions. Rudolf Carnap, for example, maintained that "[i]n physics we can easily see this de-subjectivization which has already transformed almost all physical terms [physikalische Begriffe] into purely structural terms [Strukturbegriffe]" (Carnap 1928, 20). To be sure, Carnap did not deny that the objects of scientific study are constituted by the individual. There are "individual streams of experience" which just like perceptions and feeling can be completely different from person to person, which means that they cannot be compared. There may be "certain structural aspects" [gewisse Struktureigenschaften] which are applicable to all experience streams, but it is precisely these qualities that Carnap traces back to „physical world points“ [physikalische Weltpunkte], that is, between different systems of constitution in which experience streams take place there is a distinct physical assignment. Only this can allow intersubjectivity and the

\footnotetext{
${ }^{1}$ I understand epistemology as defined by Georges Canguilhem to be the critical investigation of principles, methods, and results of a science. See Canguilhem 2006, 49-50.
} 
task of science is to find propositions that are intersubjectively transferable (Carnap 1928, 90-91, 195-200).

Thus Carnap and Reichenbach are by no means such sharp critics of sensory perception as Bachelard, for they are not of the opinion that trust in the senses directly hinders epistemological progress. They are convinced however that entirely different mechanisms of sensory perception are needed in order to create intersubjectivity. In this regard such heterogeneous thinkers as Bachelard and Carnap agree after all that perception does not play a significant role within their respective epistemology of science. Correspondingly, Bachelard was only marginally interested in what was going on in the physiology of the senses in his time. Carnap, in contrast, favorably acknowledged Gestalt psychology, because he considered it plausible that elementary experiences constitute the "basic elements of our constitutional system" (Carnap 1928, 91-93) and that they can be understood as forms [Gestalten], yet he clearly emphasized the primacy of logic in the creation of intersubjective knowledge. ${ }^{2}$

So how does this compare to the opposing, scopic epistemology? Let it be said from the start, that this latter epistemology does not limit itself in any way to individual categories such as passion, genius or intuition. Rather it conceives the act of perception as a continuum from physiological processes to social codes and interpretations, leading on to the creation of intersubjectivity. To this extent, the scopic orientation made use of perception and its study in order to avoid a physicalistic or technological reductionism and to maintain the idea that science is a genuinely human activity. Just as scientific knowledge cannot rely exclusively on rationality and logic, it cannot allow itself to be dominated by device driven media or instruments.

\section{Habsburg Empire}

Before addressing Fleck's and Polanyi's accounts more specifically, I would like to point to a number of biographical correspondences between these two authors that have some significance for an understanding of their respective positions. Both were born towards the end of the nineteenth Century in the Eastern parts of the Habsburg Empire-Fleck was born in 1896 in Lemberg and Polanyi in 1891 in Budapest. ${ }^{3}$ Both were raised in a German-speaking culture of science and both studied medicine-Fleck in Lemberg, Polanyi in Budapest, before he transferred to the Technical University in Karlsruhe, in order to study chemistry as well. From then on their paths diverged. While Fleck stayed in Lemberg-since 1918 called Lwów and belonging to Poland-he went on to study microbiology and became a physician,

\footnotetext{
2 On Carnap and Gestalt psychology see Kluck 2008, 149-181.

3 The literature on both Fleck and Polanyi is vast. On Fleck, cf. Schnelle 1982, Cohen and Schnelle 1986, and the Website of the Ludwik Fleck Center at the ETH Zürich (http://www.ludwikfleck.ethz.ch/). On Polanyi cf. Taussig et al. 2005; Mitchell 2006. Unfortunately, the long-awaited volume on Polanyi by Nye (2011) was published too late to be considered carefully for this article. I fully agree with Nye's central argument, according to which the roots for the social and cultural understanding of science are to be found in the political context of National Socialism and Communism.
} 
Polanyi went to one of the centers of science, the Kaiser-Wilhelm-Institute for Chemistry in Berlin Dahlem in order to study with the famous chemist Fritz Haber. Both actively published in their respective areas of specialization-Fleck, however, began in the 1920s to write and publish epistemological papers, mainly in Polish, but also in German, especially his main opus, The Rise and Development of a Scientific Fact that appeared with Schwabe Verlag Basel in $1935 .{ }^{4}$

At this time, Polanyi began to publish articles on philosophy of science, economics and politics. He had become a victim of the racist barbarism of National Socialism and emigrated from Berlin to Manchester in 1933, where he first continued to work as a physical chemist. National Socialism affected Fleck even more. In 1941 he was arrested by the SS and landed in Auschwitz and Buchenwald. He was not murdered because he was useful to the SS as a microbiologist who could produce a serum against typhoid fever. After the war, Fleck continued his scientific career first in Poland and later in Israel, where he died in 1961. Until then, he published widely in the field of immunology and bacteriology, writing only sporadically on epistemology, probably because he was demoralized by the fact that his major work remained without resonance. Polanyi finally moved from physical chemistry to philosophy and sociology of science in the 1940s and became professor of sociology at the University of Manchester in 1945. His main work, Personal Knowledge. Towards a Post-Critical Philosophy, appeared in 1958, at a time when he had already achieved some public acclaim.

Two aspects of these biographies seem to me to be worthy of special note and helpful in situating their respective work. Fleck developed his theory between 1925 and 1935, at a time when National Socialism and the civilizational catastrophe it unleashed was just beginning to emerge. While Fleck worked at the outer margins of the scientific European world, Polanyi developed his theories in Manchester, one of the scientific centers during the Cold War of the late 40s and 50s. This difference becomes manifest in reference to Gestalt psychology, which played an important role for both. While Polanyi extensively quotes works from Gestalt psychology, Fleck only uses the concept without concrete references. Neither Fleck nor Polanyi was an adherent of Gestalt theory in the strict sense of the word, that is, neither understood himself as a member of the Gestalt movement. However, both were interested in sensory perception from a perspective that had been stimulated by Gestalt psychology, and both exploited it for their theories of knowledge.

Although a more detailed analysis of Gestalt psychology lies beyond the scope of this paper, I would like to point out that from the 1920s onward, the Gestalt theory developed by Max Wertheimer, Wolfgang Koehler, Kurt Koffka, and some other psychologists had an enormous impact in a very short period of time. The fundamental principle is that the perceived Gestalt is not the constructed product of individual sense data-which in itself would not make sense-but rather Gestalt is understood as the fundamental unity of perception and thus of the life of the mind (Ash 1994, 90-91). This principle applies to subjective experience as well as to neurophysiological processes in the brain. The functions of the brain are analogous

\footnotetext{
${ }_{4}$ A complete bibliography of Fleck's writings can be found in Fleck 2011, 656-672.
} 
to perception, experience, intuition and thought, etc. and are to be understood holistically, and not as an isolated partial function of a random part of the brain.

Gestalt refers then to universal entities that enable us to surmount psychophysical dualities. Beyond that they have epistemological consequences, for if a scientific observation or perception has the character of a Gestalt, this means that it is not a conglomeration of individual observations, but is just somehow there at some point. The question then remaining is how a Gestalt is formed. Wertheimer spoke of the variable organization of the field of perception which is linked to determinant conditions. The conditions are also responsible for specific Gestalt tendencies and their relation to one another. This is precisely Fleck's point of departure.

\section{Thought style and Gestalt}

There exists a widely disseminated myth about observation and experiment. The knowing subject figures as kind of conqueror along the lines of Julius Caesar who wins his battles according to the formula, veni-vidi-vici. We want to know something, we make the observation or the experiment, and then we already know it (Fleck 1980, 111).

These are the polemical statements with which Fleck opens the chapter "Observation, Experiment, Experience" of his major work. For Fleck there is no world out there that is just waiting to be recognized and understood. The microscopic preparations with which the bacteriologist has to contend on a daily basis are far too complex and confusing. A first observation or measurement is always chaotic. It is neither to be understood nor interpreted and thus should not be reproduced in many cases. Therefore a slow and tedious task begins in order to determine what one actually sees. The reason for this sobering state of affairs lies, on the one hand, in the unwieldiness of the unknown object, and in the knowing subject, on the other. Observation without precondition is psychologically a nonentity (Unding). Instead Fleck postulates two types of observation: "a vague initial visual perception" (unklares, anfängliches Schauen) and "the direct perception of form" (unmittelbares Gestaltsehen) (Ibid., 121). Initial perception is undirected and without a goal, it excludes nothing and perceives nothing, it is explorative and fragmentary with no recourse to memory or experience. The perception of form, on the other hand, is directed at something; it has a closed unity and presupposes experience in a specific field of knowledge. This experience constitutes an element of the style of thought which Fleck defines as encompassing the entirety of mental preparations that enable us to see certain types of Gestalt and not others. When one first looks at something, all possibilities are still open, but when one perceives form directly, they are more or less fixed.

Those familiar with the history of attentiveness may be reminded of Fleck's typology of the differentiation between attentiveness and distraction that was of great significance for psychophysiology and the cultural theory of his time (Hagner 1998; Crary 1999). Fleck however goes beyond the theory of attentiveness by means of the concept of the perception of form. Coherent scientific observation and its 
understanding within the framework of a broader theoretical context function according to the principle of Gestalt and the relations among forms. That one form or Gestalt is visible rather than another is explained by what Wertheimer called "conditions." The essential point in Fleck's theory is that he gives these conditions a social turn. Education, habit, and belonging to a particular collective of likeminded thinkers make it impossible to recognize an object as Gestalt if this object is incompatible with the corresponding thought style.

"On the one hand, a thought style that has developed in a certain way enables one to see many forms and many applicable facts; on the other hand, it renders the seeing of other forms and other facts impossible" (Fleck 1980, 122). Fleck explicitly insists against Carnap that a thought-style is not an absolute norm of thought valid for all possible fields of knowledge. Carnap had introduced the concept of thought style in a context that was to make the fundamentally strict, mathematical-physical approach of the natural scientist also viable for the philosopher (Carnap 1928, iv). For Fleck there is no such thing as a generally articulated thought style that is generally applicable for observation because the thought collective constitutes the social conditions of scientific knowledge. An isolated researcher without a thought style and without presuppositions would be blind and thoughtless. He would not be able to come up with any new thoughts, because no Gestalt can take shape in him. And there is no prosthetic device that can change this rule in any way. Even instruments such as the microscope are constituents of the thought style and are not capable of bringing about a change in the same Gestalt from one moment to the next. A revolution of technical devices cannot come about according to Fleck, because the use of instruments leads to an expansion of all possible visible objects, producing confusion. That this plethora of possibilities is reduced to a controllable repertoire is not a question of the instrument, but of convention. Under no conditions does one see Gestalt immediately and without mediation. Rather, it is the thought-style that has to come into motion in order that scientific innovation may evolve (Fleck 1983a, 78, 81).

Therefore, Fleck pursues - as he concedes in a text written after World War II-a holistic approach which he derives from the psychology of perception. ${ }^{5} \mathrm{We}$ recognize a person or a specific facial expression without being able to explain which detail is specific or characteristic. What is more, it is imperative that we can forget these elements again. "Otherwise we cannot see the forest for the trees and the syllables do not allow us to recognize words and sentences" (Fleck 1983b, 149, 154). This independence of the whole from its parts in the process of perception is also a decisive point for Michael Polanyi in his theory.

\section{The tacit dimension of Gestalt}

In order to exemplify the concept of tacit knowledge, Polanyi often has recourse to the mechanisms of attentiveness. Through the focusing of attentiveness a holistic image is generated while in the background we can be conscious of the individual

\footnotetext{
5 The sources on perception and psychology available to Fleck remain unclear to this day. Cf. Löwy 2008.
} 
parts that are to a certain degree subsidiary, even if we do not precisely perceive them at that moment. One could also say that there are two levels of attentiveness at work here: a lower level for the individual entities and a focused perception of the larger picture. Only both forms together enable us to move from the individual to the whole. "Implicit" or "tacit" means for Polanyi that we cannot precisely explain the details of the relation between subsidiary and focused attentiveness; we cannot explain the steps from the individual part to the whole. This has to do with a "mute power" that enables us to experience and to know. Now Polanyi did not stop with these simple examples from perception, rather he saw implicit knowledge as a general key that opens all doors to the tower of knowledge.

Tacit knowledge is equally at play in theoretical and practical processes, in the precision of handcraft, in the art of the experienced diagnostician of medicine, and in the creative abilities of an artistic or scientific genius. A line of demarcation between natural and social sciences does not exist: "Assuming however that implicit thoughts would constitute an indispensible entity for all knowledge, then the ideal of obliterating all personal elements of knowledge would mean de facto the destruction of all knowledge" (Polanyi 1985, 27). Polanyi makes his indebtedness to Gestalt psychology known right at the start of Personal Knowledge, in which he concedes that it gave him the first impetus for developing a theory of knowledge. According to this, knowledge does not evolve objectively or independently of the personality. Rather, the act of knowing and producing knowledge is bound to skills that cannot be separated from the individual concerned. These skills or this knowledge are however only effective because they are mute or implicit. At this point the split between the part and the whole becomes significant. According to Polanyi, Gestalt psychology has shown "that we can recognize a physiognomy by bringing together its parts as we apprehend them, yet without being able to identify them "(Polanyi 1985, 15). For an understanding of perception and the process of scientific knowledge it is imperative that we ignore the different parts or elements of a face or complex problem in order to understand the whole.

Departing from the Gestalt, we can follow the path to the individual parts; however the reverse does not work: The path from the parts to the whole remains closed to us. The scientist first develops an adequate orientation toward the problem and then shifts "attentiveness away from individual entities toward a complete entity in which they are combined in a manner that we cannot define" (Polanyi $1985,30)$. The argument here is very similar to Fleck's. For Fleck, too, the path from initial, vague visual perception to the perception of form leads through a tunnel within which it is impossible to trace the paths exactly. Furthermore, we don't exactly know how we got out of the tunnel. Fleck considers this process to be the result of a social formation that is given through the thought collective. For Polanyi, this has to do with the "active forming of experience during the process of acquiring knowledge" (Polanyi 1985, 15). In order to explain this forming, Polanyi has recourse to categories similar to Fleck's, namely to skill, experience, training, and aesthetic judgment. There is no discussion of improving or extending the senses through prosthetic devices.

Although Polanyi refers at many points to the social and cultural conditioning of knowledge, he avoids, in contrast to Fleck, any clear discussion of the social 
formation of knowledge. This absence should not be underestimated as it constitutes a significant difference between the two theories and should be seen in the context of an idiosyncrasy, namely Polanyi's ceaseless references to the fact that we cannot do without personal or implicit parts of knowledge if knowledge as such is not to be destroyed. The defense of the personality and the absence of the social must be placed before the backdrop of the historic situation in which Polanyi developed his theory.

When Polanyi was discussing the relation between brain, mind, and machines with the mathematician Alan Turing and the philosopher John Z. Young in Manchester during the late 1940s, two diametrically opposed positions emerged which were very influential during the ensuing years (Schaffer 1999). While Turing and Young considered the brain to be a deterministic system that can be completely described through its initial state and through defined commands, thus in principle fully explaining the cognitive capacities of the human mind, Polanyi radically rejected the comparison between mind and a Turing machine, arguing that the human mind is not to be subjected to the tyranny of material mechanisms (Polanyi 1958, 261-264). In his writings he never tired from attacking logical positivism and cybernetics, behaviorism, and Soviet Communism for throwing human freedom and free choice overboard and thus degrading humans to robots (Polanyi 1951; Polanyi 1958, 36-37, 369-373). From the perspective of this aversion, it comes as no surprise that Polanyi did not wish to ascribe a very privileged position to instruments in the context of epistemology of science. Of course, Polanyi as physical chemist knew at the time that scientists cannot survive without instruments, yet in his philosophy of science he conceived them as explicators which have the ability to destroy the subtle play between distal and proximal parts of perception. For Polanyi it was a horrible idea to make everything explicable and planned, be it in a political system or a philosophical theory. Epistemological and moral convictions come together here. "Every attempt to achieve complete control over thought through explicit rules is in itself a contradiction, leading us astray at every step and is a culturally destructive move" (Polanyi 1969, 156). Somewhat polemically one could say that Polanyi joined an illustrious group of culturally conservative defenders of humanist Western values, and this was for him a fundamental issue in the Cold War era.

\section{Perception and liberty}

The tendency to understand the natural sciences in the light of values giving them the status of a specific culture was gaining momentum since the nineteenth century. At no other time did this culture have a stronger influence than during the period of Cold War when the primary goal was to demonstrate the moral, political, cultural, scientific, and technical superiority of Western democracies over communism. Thus in 1953, during a famous congress on Science and Freedom held at the University of Hamburg, Polanyi held the battle against communism to be unavoidable and "that by founding institutions that promote science the state recognizes the existence of a sphere of independent ideas and independent people, thus conceding that the 
demands of this sphere have the same status as the political and material interests of society that are protected by the state" (Polanyi 1954, 26). ${ }^{6}$

The demand for autonomy of science in light of the practice of eugenics and Auschwitz, Lyssenkoism, and Soviet communism had two entirely different faces during the post-war period. For the sociologist Robert Merton this autonomy could be insured only if science pursued the ideal of neutrality, value-free judgments, and objectivity that would eliminate subjective elements. Universalism, non-partisanship, organized skepticism, and communism were the norms that constitute truly independent science (Merton 1985). Against Merton's claim, Polanyi defended the importance of passion and partisanship for scientific knowledge. His goal was to protect the personal idiosyncrasy of knowledge against a complete explication. In Merton's scenario, establishing science as cultural accomplishment means the assimilation of science to an interest- and value free situation given only in nature. In Polanyi's scenario, science as cultural accomplishment is established by the autonomous individual, who may neither be subordinated to any political or religious norms, nor may the autonomous individual subordinate itself to any machines or media.

With this shift from epistemology to ethics, Polanyi introduced a topic into the philosophy of science that Fleck had not explicitly dealt with in his writings before the war. This was to be different in the postwar era. In 1960, one year before Fleck's death, the long forgotten and fatally ill scientist wrote "Toward a free and human science" in response to a discussion in the journal Science which remained unpublished during his life. There he complains that the cultural mission of science has been damaged by becoming the midwife of politics and industry. Fleck insists on the autonomy of science the recipe for which was to be his old theory of the thought collective which he now summarizes, going beyond his earlier thesis with the claim that epistemological activity consists of three inseparably linked components: the subject, the object, and the community. Understanding their interplay could enlighten the sciences as to the genesis of ideas and the nature of scientific truth which changes from "something static and ossified into a dynamic, developing creative human truth" (Fleck 1983c, 180). Fleck is more explicit here than in his earlier texts in emphasizing that scientific activity is couched in a moral context and that the goal should be to maintain a humane science. Nor had the subject previously played such a dominant role. On both counts there is a noticeable proximity to Polanyi.

I have digressed somewhat from the initial question about the relation of perception and knowledge with regard to the respective media; by focusing on the context in which these connections were closely intertwined, two things are to be made clear. First of all, neither Polanyi nor Fleck was interested in achieving a oneto-one transfer from one field of knowledge to another. Fleck referred in a most general way to Gestalt psychology, using the concept of Gestalt and a few of its key ideas. Not until twelve years after publishing his major work did he name Gestalt psychology as a source for his approach. For Polanyi, the assimilative process was more complex. He had recourse to Gestalt psychology, the psychophysiology of

\footnotetext{
${ }_{6}$ On Polanyi's political liberalism, cf. Jacobs and Mullins 2008.
} 
attentiveness, the physiology of the senses, and named countless other experimental investigations in physiology in order to make his concept of tacit knowledge more plausible. Polanyi was interested in circumscribing an entire field of phenomena, not in a single doctrine. Decisive is the fact that he made the play of attentiveness, the active formation of experience, and the perception of Gestalt in the sense of tacit knowledge the sine qua non of the dynamics of scientific knowledge.

Second, epistemology cannot so easily escape the clutches of the very sciences it is analyzing. Historical epistemology as well as the philosophy of science are oriented in their approach toward specific sciences. This relation becomes viable in the field of history and must therefore be observed there. As divergent as their approaches may have otherwise been, modern physics was the main source for the metatheories of Bachelard and Carnap; for Fleck and Polanyi it was Gestalt psychology which was sufficiently scientific to refuse the reduction of logical and instrumental conditions for knowledge production; and sufficiently humanistic to preserve the idea of free human beings creatively working in the sciences. It is precisely this continuity between the physiological conditions of the sense apparatus and the complex epistemic operations that Fleck and Polanyi took for granted. A shift of epistemic energy from the sense organs to scientific devices, as Bachelard postulates, is excluded here just as is the assumption of a rupture, a break as the decisive motivating force in the dynamics of knowledge. Fleck and Polanyi acknowledge discontinuities and shifts, too, but these are adapted to the formation of Gestalt, that is, a changed attitude toward thought. That means that they are honed to the speed of psychophysiological and social processes and not to technological innovations that are continuously producing new devices.

\section{Conclusions}

What conclusions may we draw from all this for historical epistemology? With regard to its history, it is evident that prior to Kuhn's discovery of Fleck in the 1960s and his confession that many of his ideas could be found in the work of the Polish bacteriologist, Fleck was basically unknown in the community of philosophers of science. As I see it, this has to do with the fact that the latter as well as sociologists of science were in search of a certitude-after the experiences of National Socialism and Stalinism and the desire for epistemological-political robustness in times of Cold War-provided by the description and interpretation of scientific knowledge (Reisch 2005). Fleck placed precisely these certitudes in question. It is well-known that Kuhn's Psychology of Research first laid the groundwork on which the germs of Fleck's theory could gradually take hold and thrive. With this, the camera shifted its focus away from the hard criteria of logic and instruments to the so-called soft criteria of thought style and social communities.

Polanyi was not in need of historical midwifery. His solid connection between knowledge and morality was clearly the consequence of his experiences in the age of extremes. It followed that the positing of the "mute force" would serve to preserve the realm of science from planning, patronization, and remote control. With this position, a knowledge free of all possible social, technological, and 
economic contaminants is postulated. This epistemological concept, which makes the assumption of implicit knowledge into an indispensable precondition of the explicit, did not find resonance among proponents of the theory of science oriented toward objectivity and logic. People were wary of metaphysical assumptions without evidence which, in a very different way, undermine purified rational knowledge systems. Nor did historians of science really warm to Polanyi's theses. If certain knowledge is not explainable, they objected, it is not accessible to adequate historical or sociological study either.

With the emergence of the so-called practical turn in the 1980s, the shift in emphasis from theory to the practice of sciences, Polanyi's reflections were taken up again and refined. Harry Collins, for example, saw in experimental practice much more than just a set of rules for testing theories. The manner in which an experimental design is constructed, how instruments are used, and how knowledge circulates in a work group contains elements that are locally anchored and cannot be precisely explicated. Collins calls this the "enculturational versus algorithmical conception of scientific practice" and has subsequently developed a comprehensive sociological theory of tacit knowledge (Collins 1992, 56-57, 171; Collins 2010). Since the 1990s, science studies, while focusing on the material context of instruments and apparatus, have also taken into consideration craftsmanship and skill, physical discipline, and the dependence of information on local conditions. This balanced perspective, taking into account the material and the social conditions of scientific knowledge production likewise, has been responsible for avoiding a technological or instrumental determinism in historical epistemology, such as can often be observed in the media sciences. This could be one of the most important consequences of working with Fleck and Polanyi's theories. On the one hand, it was not possible to learn from either one about the significance of the media or instruments because they both favored a model of knowledge that underestimated the importance of media, thus setting the limits of their theories. On the other hand, it was quite possible to learn from them that media are also incorporated into a complex network of action that does not follow one single logic or order. Both Fleck and Polanyi pointed out that the relation of perception and knowledge is multifaceted, more so than suggested by the ideas of the substitution of perception through logic or instruments.

In the meantime, Gestalt psychology has become history and can no longer assume the role it played for Fleck and Polanyi. Science studies have gladly taken the historical and sociological components of their theories into their fold, yet the psychological aspects have been abandoned. One should not overlook the fact that there is a fundamental difference between Kuhn's "psychology" and Collins' "enculturation." The question, whether or not the psychophysiology of senses can be productively used for historical epistemology, is not on the agenda of current discussions. There may be good reasons for this absence, because an answer to this question would not be able to avoid the fact that cognitive psychology has since been situated under the protectorate of the neurosciences. Is something like neuroepistemology appearing on the horizon, comparable to neuromarketing or neuroaesthetics which claim to make meaningful statements about the perception of our world? I don't think so, but after the social and material components of the 
origin of knowledge have been thoroughly examined, it might perhaps be worthwhile to look at scientific practices again in light of anthropological and psychological cross connections and roots, taking experience, intuition, discipline, and convention into consideration.

Why should experimental works of actual laboratory research not be taken into consideration together with historical, ethnological, and sociological investigations? Such a project has hardly been ventured, but perhaps we would be more trusting of such an undertaking were we to remember that the link between psychology and epistemology, enabling the fundamental expansion of our understanding of the dynamic and complexity of scientific knowledge, was forged but a few short decades ago.

\section{References}

Ash, M. G. (1994). Gestalttheorie und logischer Empirismus. In L. Danneberg, A. Kamlah, \& L. Schäfer (Eds.), Hans Reichenbach und die Berliner Gruppe (pp. 87-100). Braunschweig: Vieweg.

Bachelard, G. (1951). L'activité rationaliste de la physique contemporaine. Paris: Presses Universitaires de France.

Canguilhem, G. (2006). Philosophie und Wissenschaft: Gespräch mit Alain Badiou (1964). In Idem, Wissenschaft, Technik, Leben. Beiträge zur historischen Epistemologie (pp. 49-68). Berlin: Merve.

Carnap, R. (1928). Der logische Aufbau der Welt. Berlin: Weltkreis.

Carnap R, Hahn H, Neurath O (1981). Der Wiener Kreis der wissenschaftlichen Weltauffassung [1929]. In O. Neurath, Gesammelte philosophische und methodologische Schriften, vol. 1 (pp. 299-315). Vienna: öbv.

Cohen, R. S., \& Schnelle, Th. (Eds.). (1986). Cognition and fact. Materials on Ludwik Fleck. Dordrecht/ Boston: Reidel.

Collins, H. M. (1992). Changing order. Replication and induction in scientific practice. Chicago: The University of Chicago Press.

Collins, H. M. (2010). Tacit and explicit knowledge. Chicago: The University of Chicago Press.

Crary, J. (1999). Suspensions of perception. Attention, spectacle, and modern culture. Cambridge/MA: MIT Press.

Fleck, L. (1980). Entstehung und Entwicklung einer wissenschaftlichen Tatsache [1935]. Frankfurt a. M.: Suhrkamp.

Fleck, L. (1983a). Über die wissenschaftliche Beobachtung und die Wahrnehmung im Allgemeinen [1935]. In Idem, Erfahrung und Tatsache. Gesammelte Aufsätze (pp. 59-83). Frankfurt a. M.: Suhrkamp.

Fleck, L. (1983b). Schauen, Sehen, Wissen [1947]. In Idem, Erfahrung und Tatsache. Gesammelte Aufsätze (pp. 147-174). Frankfurt a. M.: Suhrkamp.

Fleck, L. (1983c). Krise in der Wissenschaft. Zu einer freien und menschlicheren Naturwissenschaft [1960]. In Idem, Erfahrung und Tatsache. Gesammelte Aufsätze (pp. 175-181). Frankfurt a. M.: Suhrkamp.

Fleck, L. (2011). Denkstile und Tatsachen. Gesammelte Schriften und Zeugnisse. Frankfurt a. M.: Suhrkamp.

Hagner, M. (1998). Aufmerksamkeit als Ausnahmezustand. In N. Haas, R. Nägele, \& H.-J. Rheinberger (Eds.), Aufmerksamkeit (pp. 273-294). Eggingen: Edition Isele.

Jacobs, S., \& Mullins, P. (2008). Faith, tradition, and dynamic order: Michael Polanyi's liberal thought from 1941 to 1951. History of European Ideas, 34, 120-131.

Janssen, J. (1888). Banquet Annuel de la Société. Discours de M. Janssen. Bulletin de la Société de Photographie, 4, 167.

Jay, M. (1994). Downcast Eyes. The denigration of vision in twentieth-century French thought. Los Angeles/Berkeley: University of California Press. 
Jha, S. R. (2002). Reconsidering Michael Polanyi's philosophy. Pittsburgh: University of Pittsburgh Press.

Kittler, F. (1999). Optische Medien, Berliner Vorlesung. Berlin: Merve.

Kluck, S. (2008). Gestaltpsychologie und Wiener Kreis. Stationen einer bedeutsamen Beziehung. Freiburg: Alber.

Kuhn, Th. S. (1970). Logic of discovery or psychology of research? In I. Lakatos \& A. Musgrave (Eds.), Criticism and the growth of knowledge (pp. 1-23). Cambridge: Cambridge University Press.

Löwy, I. (2008). Ways of seeing: Ludwik Fleck and Polish debates on the perception of reality, 1890-1947. Studies in the History and Philosophy of Science, 39, 375-383.

Merton, R. K. (1985). Die normative Struktur der Wissenschaft. In Idem, Entwicklung und Wandel von Forschungsinteressen. Aufsätze zur Wissenschaftssoziologie (pp. 86-99). Frankfurt a. M.: Suhrkamp.

Mitchell, M. T. (2006). Michael Polanyi: The art of knowing. Wilmington, DE: ISI Books.

Nye, M. J. (2011). Michael Polanyi and his generation. Origins of the social construction of science. Chicago: The University of Chicago Press.

Polanyi, M. (1951). The logic of liberty. Reflections and rejoinders. London: Routledge and Kegan Paul.

Polanyi, M. (1954). Reine und angewandte Wissenschaften und ihre angemessenen Organisationsformen. In Wissenschaft und Freiheit. Internationale Tagung Hamburg, 23.-26. Juli 1953 (pp. 17-32). Berlin: Grunewald.

Polanyi, M. (1958). Personal knowledge. Towards a post-critical philosophy. Chicago: The University of Chicago Press.

Polanyi, M. (1969). Knowing and being. Chicago: The University of Chicago Press.

Polanyi, M. (1985). Implizites Wissen [1966]. Frankfurt a. M.: Suhrkamp.

Reichenbach, H. (1962). The rise of scientific philosophy (8th ed.). Los Angeles/Berkeley: University of California Press.

Reisch, G. A. (2005). How the Cold War transformed philosophy of science: To the icy slopes of logic. Cambridge: Cambridge University Press.

Schaffer, S. (1999). OK Computer. In M. Hagner (Ed.), Ecce cortex. Beiträge zur Geschichte des modernen Gehirns (pp. 254-285). Göttingen: Wallstein.

Schnelle, Th. (1982). Ludwik Fleck - Leben und Denken. Freiburg: Alber.

Smith, B. (1988). Gestalt theory: An essay in philosophy. In Idem (Ed.), Foundations of Gestalt Theory (pp. 11-81). Munich/Vienna: Philosophia.

Taussig Scott, W., \& Moleski, M. X. (2005). Michael Polanyi: Scientist and philosopher. Oxford: Oxford University Press.

Zittel, C. (2012). Ludwik Fleck and the concept of style in the natural sciences. Style as a scientific, epistemological and aesthetic category. Studies in East European Thought, 64(1-2), 55-82. 